\title{
The Revelation Narratives: Analyses and Theological Reflections on Exodus, Deuteronomy, and Classical Midrash
}

Avraham Shammah

Exodus 19-24 and Deuteronomy 4-5 present different descriptions of revelation. A comparison between the two sections raises philosophical and theological questions, some of which are hinted at in classical rabbinic literature. It is not my intention in this article to present a detailed exegetical analysis of these passages, but rather to identify several significant and fundamental characteristics of their description of divine revelation. ${ }^{1}$

\section{The Central Narrative in Exodus: Revelation as Vision}

A fundamental characteristic of the depiction of the revelation in Exodus 19 is vision; there is a human viewer and a divine object of vision. Revelation, as the term implies, is visual, and is described in several of the central verses as a single objective vision perceived by all. Those who see it are witnesses to an event external to themselves, an event in which the image of God emerges from his celestial abode and descends to earth: "For on the third day the Lord will come down, in the sight of all the people, on Mount Sinai. ... Moses led the people out of the camp toward God. . . Now Mount Sinai was all in smoke, for the Lord had come down upon it" (Exod. 19:11-18). ${ }^{2}$ 
The text declares that human beings are forbidden to enter the sphere of the divine, and therefore the people must be restricted to the foot of the mountain and prevented even from touching its edge: "You shall set bounds for the people round about, saying, 'Beware of going up the mountain or touching the border of it. Whoever touches the mountain shall be put to death.' Moses led the people out of the camp toward God ... and they took their places at the foot of the mountain" (12-17).

The assumption inherent to the biblical text is that the heavens are the abode of God while the earth was given to man: "The heavens belong to the Lord, but the earth He gave over to man" (Ps. 115:16). When God crossed this boundary and descended to the mountain, he removed the people from the mountain so that the two spheres would not mix. He also disrupted the tranquility of the earth. The descent of God upon the mountain is, therefore, accompanied by a terrifying upheaval: "There was thunder, and lightning, and a dense cloud upon the mountain, and a very loud blast of the horn; and all the people who were in the camp trembled.... Now Mount Sinai was all in smoke, for the Lord had come down upon it in fire; the smoke rose like the smoke of a kiln, and the whole mountain trembled violently" (16-18).

The context makes clear that the cloud and the smoke do not function here as a screen, but are part of the upheaval and, along with the thunder, the lightening, and the horn, instill fear of God.

It therefore transpires that while the connection between God and man is devoid of physical contact, it includes visual contact in the form of man observing God from across the barrier. This empirical viewing requires human preparation and the people are, therefore, commanded to sanctify themselves by laundering their garments and abstaining from marital relations: "And the Lord said to Moses, 'Go to the people and warn them to stay pure today and tomorrow. Let them wash their clothes. Let them be ready for the third day.'. . . Moses came down from the mountain to the people and warned the people to stay pure, and they washed their clothes. And he said to the people, "Be ready for the third day: do not go near a woman"' $(10-15)$.

What did the people see? This question leaves the reader in uncertainty because of the content's inherent tension and utter sublimity. These are boldly worded verses describing divine revelation to a select group. This can be seen especially in verses 24:9-10: "Then Moses and Aaron, Nadab and Abihu, and seventy elders of Israel ascended; and they saw the God of Israel: under His feet there was the likeness of a pavement of sapphire, like 
the very sky for purity. Yet $\mathrm{He}$ did not raise His hand against the leaders of the Israelites; they beheld God." 3

These verses contrast with verse 20:15: "All the people witnessed the thunder and lightning, the blare of the horn and the mountain smoking; and when the people saw it." It seems to me that the intention of this verse is to clarify that they saw these things but no more; they did not see God.

In addition to these verses, there is also a description of what will happen in the future: "The Lord will come down, in the sight of all the people" (Exod. 19:11). However, this verse also creates uncertainty; it announces and anticipates the spectacle of the descent of God, but a description of the people actually witnessing the descent itself is missing. Furthermore, the verse does not say that the people will see God with their own eyes, but that God will descend before their eyes: the object of the vision is the descent, not God. ${ }^{4}$

Verses 20-25 state that beholding the deity is forbidden, perhaps even impossible, and will result in God "breaking out" against those who attempt to perceive him. ${ }^{5}$ These verses limit God's presence to the summit of the mountain, where it can be seen by the people only from afar: "The Lord came down upon Mount Sinai, on the top of the mountain, and the Lord called Moses to the top of the mountain. . . ' Go down, warn the people not to break through to the Lord to gaze, lest many of them perish . . . lest the Lord break out against them ... but let not the priests or the people break through to come up to the Lord, lest He break out against them."

These verses stand in contrast to verses 10-19 that describe God's descent upon "the mountain" and even "the whole mountain": "The Lord will come down ... on Mount Sinai ... a dense cloud upon the mountain. . . . Now Mount Sinai was all in smoke ... the Lord had come down upon it ... the whole mountain trembled violently." 6

\section{Foreshadowing in Exodus of the Auditory Revelation in Deuteronomy}

Thus far I have emphasized the visual aspect of the narrative in Exodus. Attention must also be paid to its verbal elements, to its discourse. The outstanding feature of the verses that I have described so far would seem to be the absence of verbal communication between God and man. Discourse as a component of revelation is entirely absent from chapter 19. Moses speaks to God and hears his reply, yet these words are not part of the revelation itself, but rather ancillary to it, providing instructions relating to the revelatory event, and similar matters. 
Although there is a brief conversation in verse 9 ("And the Lord said to Moses, 'I will come to you in a thick cloud, in order that the people may hear when I speak with you."') it can be argued that this segment is not part of the narrative sequence of the story, as can be seen in verses 8 and 9:

8a: All the people answered as one, saying, "All that the Lord has spoken we will do!"

8b: And Moses brought back the people's words to the Lord.

9a: And the Lord said to Moses, "I will come to you in a thick cloud, in order that the people may hear when I speak with you...."

9b: Then Moses reported the people's words to the Lord.

Verse $9 \mathrm{~b}$ puzzled the sages because the people's words reported to God by Moses are not specified prior to this verse. ${ }^{7}$ It would appear that according to the peshat (plain, contextual meaning), verse $9 \mathrm{~b}$ is a resumptive repetition (Weideraufnahme, or epanalepsis) of $8 \mathrm{~b}$. This means that $9 \mathrm{a}$ is not part of the narrative sequence but a parenthetical expression, ${ }^{8}$ a flash, a secondary voice, that serves to foreshadow a similar ${ }^{9}$ event in Deuteronomy (as I will explain below). ${ }^{10}$ Segment $9 a$, which deviates from the sequence, causes segment $9 b$ to refer back to $8 b$, and thereby return to the narrative sequence.

The position of the Decalogue in Exodus requires particular attention because it is quintessentially divine discourse. However, even this famous speech is not described in Exodus as the result of the descent of God or as part of the revelation. The Decalogue surprises the reader because neither verses 10-19, announcing God's descent, nor the following verses, 20-25, indicate that God is going to speak to the people. Moreover, the opening of the Decalogue speech at the beginning of chapter 20 ("God spoke all these words, saying") is odd in that it lacks an indirect object indicating to whom God spoke these words. In other words, the text does not explicitly state that the words were heard by the audience for whom they were intended. ${ }^{11}$

There is no choice but to acknowledge the existence of two possible readings. According to the first reading, the Decalogue is not a continuation of the preceding verse, in which case the revelation remains purely visual; as the descriptive narrative continues in the verse immediately following the conclusion of the Decalogue (20:15): "All the people witnessed the thunder and lightning, the blare of the horn and the mountain smoking; and when the people saw it, they fell back and stood at a distance." 12 This reading rests on the verses constituting the central narrative axis. According to the other reading, the 
Torah's intention is to append a long series of legal passages to the revelation narrative, continuing until chapter 23: the Decalogue, the laws (mishpatim) beginning in verse $21: 1$, sections of law, and collections of written commandments as elaborated in 24:4-12,13 and ending with the ceremony marking the sealing of the covenant and the people's acceptance of the commandments:

He set up an altar and they offered burnt offerings and sacrificed bulls as offerings of well-being to the Lord. Moses took one part of the blood and put it in basins, and the other part of the blood he dashed against the altar. Then he took the record of the covenant and read it aloud to the people. And they said, "All that the Lord has spoken we will faithfully do!" Moses took the blood and dashed it on the people and said, "This is the blood of the covenant that the Lord now makes with you concerning all these commands" (Exod. 24:4-8).

This second possible reading, which includes the commandments, is another foreshadowing of a similar event that will occur in the future in Deuteronomy: the giving of the law and the covenant that are signaled as early as the beginning of chapter 19, in verses 3-6: "Thus shall you say to the house of Jacob and declare to the children of Israel. ... Now then, if you will obey Me faithfully and keep My covenant." These verses foreshadow what is to come in Deuteronomy as indicated by the phrase "you shall be My treasured possession among all the peoples" as well as "if you will obey Me faithfully" (19:5), which are characteristic of the style of Deuteronomy. ${ }^{14}$

In addition, it appears that the section immediately following the Decalogue (20:15-19) also foreshadows Deuteronomy:

All the people witnessed the thunder and lightning, the blare of the horn and the mountain smoking; and when the people saw it, they fell back and stood at a distance. "You speak to us," they said to Moses, "and we will obey; but let not God speak to us, lest we die." Moses answered the people, "Be not afraid." .. . So the people remained at a distance, while Moses approached the thick cloud where God was. The Lord said to Moses: Thus shall you say to the Israelites: You yourselves saw that I spoke to you from the very heavens.

Verses 16 and 19 mention God's verbal communication with the people: "let not God speak to us"; "I spoke to you." However, the words at the 
beginning of verse 18 ("So the people remained at a distance") appear to be a resumptive repetition of the end of verse 15 ("they fell back and stood at a distance"). ${ }^{15}$ This means that the intermediary verses (16-17) can be defined as parenthetical or outside the narrative sequence. ${ }^{16}$ Moreover, verse 15 does not mention that the people heard speech, only that they "witnessed the thunder and lightning, the blare of the horn, and the mountain smoking," and therefore, in this respect also, verses 16-17 are not a continuation of verse 15 . Verse 19, which describes verbal communication from heaven, is also not part of the narrative sequence, because verbal communication from heaven is not mentioned at all in Exodus, and therefore the didactic lesson- "You yourselves saw that I spoke to you from the very heavens" (20:18) - has no basis. The inescapable conclusion is that verse 19 is nonsequential, and divine verbal communication is not a part of the central narrative axis in Exodus, but rather characteristic of the account of revelation in Deuteronomy. ${ }^{17}$

In conclusion, it would appear that the core of the revelation in Exodus 19 is essentially visual ${ }^{18}$ and in fact supports the first reading. ${ }^{19}$ This core is surrounded by legal discourse, and enveloped in laws and statements about divine speech. This outer shell foreshadows what is to come in Deuteronomy, as I will attempt to explain in the following pages.

\section{Deuteronomy: The "Audio" Revelation}

The description of the event on Mount Horeb in Deuteronomy is very complicated, although less so than that in Exodus. As thorough exegetical analysis is outside the scope of this paper, I will address only the essential points and their inherent theological significance.

The narrative in Deuteronomy takes for granted a literary conception that the permanent abode of God is in the heavens. ${ }^{20}$ Unlike in Exodus, where God pierces the veil and descends to the mountain, in Deuteronomy He does not come down to the mountain, and the people see no image. Furthermore, the axis linking man and God is switched from "video" to "audio":

The day you stood before the Lord your God at Horeb, when the Lord said to Me, "Gather the people to Me that I maylet them hear My words." ... You came forward and stood at the foot of the mountain. The mountain was ablaze with flames to the very skies, dark with densest clouds. The Lord spoke to you out of the fire; you heard the sound of words but perceived no shape-nothing but a voice . . . since you saw no 
shape when the Lord your God spoke to you at Horeb out of the fire (Deut. 4:10-15).

Has any people heard the voice of a god speaking out of a fire, as you have, and survived? (4:33)

The Lord spoke those words - those and no more-to your whole congregation at the mountain, with a mighty voice out of the fire and the dense clouds. ... When you heard the voice out of the darkness, while the mountain was ablaze with fire ... [you] said, "The Lord our God has just shown us His majestic Presence, and we have heard His voice out of the fire; we have seen this day that man may live though God has spoken to him ... if we hear the voice of the Lord our God any longer, we shall die. For what mortal ever heard the voice of the living God speak out of the fire, as we did, and lived?" (5:19-23)

In these verses the voice is heard from within the fire, and the text ignores the question of the location of the speaker. In another verse, Deuteronomy 4:36, what was described above as the divine voice heard from the fire is explained by an intra-biblical interpretation: "From the heavens He let you hear His voice... on earth $\mathrm{He}$ let you see His great fire ... and from amidst that fire you heard His words." God uttered sound from heaven and on earth revealed his fire, out of which were heard the words spoken in heaven. It is possible that the verse "the mountain was ablaze with flames to the very skies" (Deut. 4:11) means that the voice heard from heaven is the voice heard from the fire, because the mountain burns with fire that reaches to the heavens.

In contrast to Exodus, Deuteronomy is characterized by the distance between man and God. The closeness in Exodus, expressed in language connoting vision, is replaced by distance. Moreover, the visual concepts in Exodus are converted in Deuteronomy to a different kind of vision, and several verses include an intra-biblical interpretation of the matter:

But take utmost care and watch yourselves scrupulously, so that you do not forget the things that you saw with your own eyes and so that they do not fade from your mind (Deut. 4:9).

It has been clearly demonstrated to you that the Lord alone is God; ... on earth He let you see His great fire (4:35-6).

And said, "The Lord our God has just shown us His majestic Presence, and we have heard His voice out of the fire; we have seen this day that man may live though God has spoken to him" (5:21). 
"The things that you saw with your own eyes" is a general expression for the experience of the sublime event. It refers to cognitive realization rather than visual perception. "It has been demonstrated to you" that the Lord is God, and you have even seen his majesty (in the cognitive sense) but you did not perceive a visual image other than fire. ${ }^{21}$

Moreover, and most significantly, Deuteronomy does not merely shift from visual revelation to phonetic, vocal revelation-to the acoustic and the auditory. It becomes verbal, transforming into discourse and speech. The revelation in Deuteronomy is verbal and lingual. In Deuteronomy, unlike Exodus, the Decalogue is the core of the revelatory event and its purpose; and the content is directed to specific listeners: "When the Lord said to me, 'Gather the people to Me that I may let them hear My words.' ... The Lord spoke to you. . . He declared to you the covenant that He commanded you to observe, the Ten Commandments; At the same time the Lord commanded me to impart to you laws and rules" (Deut. $4: 10-14){ }^{22}$

Unlike a vision, which is by nature fleeting, the verbal, instructional revelation in Deuteronomy establishes an ongoing, eternal experience. The speaking voice, in its strict phonetic, vocal sense, was heard only once: "The Lord spoke those words - those and no more ... with a mighty voice." (5:19). However, the verbal logos continues to be heard and persists within human consciousness and attention to it never wanes. The eternal validity of the verbal content became fixed permanently in Deuteronomy in three ways: (1) the prohibition against forgetting, (2) the commandment to learn and to teach one's children, and (3) the graphic representation on stone tablets. All three appear only in Deuteronomy, not in Exodus. ${ }^{23}$

But take utmost care and watch yourselves scrupulously, so that you do not forget the things that you saw with your own eyes and so that they do not fade from your mind as long as you live. And make them known to your children and to your children's children ... when the Lord said to $\mathrm{Me}$, "Gather the people to Me that I may let them hear My words, in order that they may learn to revere Me as long as they live on earth, and may so teach their children." ... He declared to you the covenant ... the Ten Commandments; and He inscribed them on two tablets of stone (Deut. 4:9-13).

He inscribed them on two tablets of stone, which He gave to me (5:19). 


\section{The Commandment of Hakhel ("Gathering the People")}

The commandment to learn and to teach, and to transmit the Torah to the next generation, was reinforced in Deuteronomy in the ceremony of hakhel:

Moses wrote down this Teaching ... when all Israel comes ... you shall read this Teaching aloud in the presence of all Israel. Gather the peoplemen, women, children ... that they may hear and so learn to revere the Lord your God and to observe faithfully every word of this Teaching. Their children, too, who have not had the experience, shall hear and learn to revere the Lord your God ... as long as they live in the land (Deut. 31:9-13).

The similarity between these verses and the description of the revelation on Horeb is obvious: "Gather the people to Me that I may let them hear My words, in order that they may learn to revere Me as long as they live on earth, and may so teach their children" (Deut. 4:10). It would appear that this gathering for hearing and learning was directed toward the goal of internalizing the revelation. ${ }^{24}$

Moreover, the comprehensive obligation to teach both oneself and one's children, the repeated study of the laws, and constant discussion of the commandments, "when you stay at home and when you are away, when you lie down and when you get up" (Deut. 6:7), inscribing them on doorposts and gates-all of these commandments are characteristic of Deuteronomy. ${ }^{25}$ They are connected to the total awareness that Deuteronomy establishes, the basis of which is the eternity of its verbal content. Unlike a vision, which can become faded and blurred and cannot be passed on to the next generation, the logos is designed to be an experience of perpetual awareness, a continuing revelation grounded in internal human cognitive processes. ${ }^{26}$ Deuteronomy emphasizes not only that the voice of God spoke, but also that the speaker directed his speech to his listeners and that the listeners comprehended; in other words, it accentuates the processes of listening and paying attention:

That I may let them hear My words (4:10).

You heard the sound of words (12).

Has any people heard the voice of a god ... as you have? (33).

He let you hear His voice... you heard His words (36).

When you heard the voice ... we have heard His voice ... if we hear the 
voice of the Lord our God any longer. ... For what mortal ever heard the voice of the living God (5:20-23).

Even when the active voice stops, the internal listening continues, and the memory of the logos serves as an active cognitive experience.

\section{From Vision to Speech: Theological Implications}

There is potential theological significance to this discussion. Deuteronomy confronts the reader with a somewhat anomalous situation. As the divine moves farther away from the human, revelation becomes grounded in an increasingly human level of cognition and awareness. It is not my intention here to discuss cognition or the characteristics of visual versus verbal cognitive processes. In any case, in the literary symbolism used in Deuteronomy, the distancing of God is symbolized by the distancing of the vision; revelation is found in the verbal listening. Intuitively (and symbolism is based on intuition), verbal auditory processes are understood to be internal human processes, part of the human cognitive processing that is hermeneutic and dynamic. In contrast, visual cognitive processes are understood, intuitively and symbolically, to be objective and external, not requiring active hermeneutic processing. In the legal world, in the laws of evidence, when objectivity is required, nothing is better than eyewitness testimony. Moreover, it is obvious that verbal communication is quintessentially human, one of the defining human attributes, distinguishing him from other living creatures. ${ }^{27}$

This distinction between Exodus and Deuteronomy, between sight and sound, vision and hearing is reflected in a midrash in Mekhilta de-Rabbi Yishamael:

Rabbi says: "And so, what did God tell Moses to tell the People of Israel, or what did the People of Israel ask Moses to tell God? They said: 'We want to hear from the mouth of our king. One who hears from across a partition is not like one who hears from the king himself.' The Holy One said, 'Give them what they want' - 'that the people may hear when I speak with you' (Exod. 19:9). Another interpretation: They said: 'We want to see our king; hearing is not the same as seeing.' God said, 'Give them what they ask for' . . ' the Lord will come down, in the sight of all the people” $(19: 11){ }^{28}$ 
Both interpretations reflect the tension indicated above. The first opinion understands the revelation as auditory, while the second understands it as visual.

The dichotomy between the descent upon the mountain as related in Exodus and the voice from heaven in Deuteronomy is reflected in another midrash in the Baraita de-Rabbi Yishmael in Sifra chapter 1:

Two verses contradict each other while a third verse decides between them. One verse says: "The Lord came down upon Mount Sinai, on the top of the mountain" (Exod. 19:20). The other verse says: "I spoke to you from the very heavens" (Exod. 20:19). ${ }^{29}$ The verse that decides between them: "From the heavens He let you hear His voice" (Deut. 4:36). This teaches us that he lowered ... the highest heavens to the top of the mountain and spoke to them from the heavens. ${ }^{30}$

This midrash from the Sifra reconciles the two verses. ${ }^{31}$

\section{Personal Hearing and Active Hearing in Classical Midrash: Sinai as a Beit Midrash}

The concept of hearing, so prominent in Deuteronomy, is intensified in classical midrash and even transforms from human hearing in general to uniquely personal hearing. For example, it is written in the Mekhilta de-Rabbi Yishmael: “'All the people witnessed the thunder and lightning' (Exod. 20:15) —Great thunder! Much lightening! How many claps of thunder were there? How many bolts of lightning? Each man would be allowed to hear according to his capacity, as it is said, 'The voice of the Lord is power; the voice of the Lord is majesty" (Ps. 29:4). ${ }^{32}$

The author of the midrash interprets the words of the verse "the voice of the Lord is power" not as referring to the power of God, but rather to the receptive attention capacity of each individual! In another midrash, the sages describe hearing as understanding and interpreting as active attention:

"Watched over him" (Deut. 32:10)—with the Ten Commandments. This teaches that as the commandment left the mouth of God, the People of Israel looked at him and knew how much midrash there was in it and how much halakhah, how many lenient precepts and how many strict precepts, and how many gezerot shavot [an interpretive rule based upon comparison]. ${ }^{33}$ 
The author of the midrash understood the phrase "watched over him" to mean the endowment of wisdom which includes the ability to interpret.

Both concepts of hearing, the idea that each person hears according to his ability and the theory of interpretive hearing, have a common denominator. Both come from the world of the sages and both reflect how the beit midrash was brought to Horeb, and Sinai brought to the rabbinic yeshivah. To a large extent the sages bound together the Written and Oral Torahs. Having done so, they projected their own activities in the beit midrash back on the People of Israel on Mount Sinai, and the method of study of their ancestors on Mount Horeb became a paradigm for their own study. Another layer of meaning was poured into the eternal vessel of the ongoing revelation: from this point on their feet did not move from the foot of Mount Sinai; reflective attention and active listening flourished and intensified.

The beit midrash thus became a place of revelation, as can be seen in the Tosefta:

"The sayings of the wise are like goads, like nails fixed in prodding sticks. They were given by one Shepherd" (Eccles. 12:11) — The words of Torah are also eternal life as it is said, "She is a tree of life" (Prov. 3:18). The verse says "fixed" [literally, "planted"] - Just as plants increase and multiply, so too do words of Torah. "Prodding sticks" [literally, "masters of assemblies"] — those who congregate and sit down in an assembly and declare what is impure to be impure, and what is pure to be pure.... Lest a man will say to himself, "The school of Shammai declares it impure and the school of Hillel declares it pure, why should I continue to study Torah?" The Torah teaches us: "sayings" [literally, "words"] — "the words," "these are the words" (Deut. 1:1), "all these words" (Exod. 20:1 ) — “were given by one Shepherd.” One God created them, one leader gave them, the Master of all deeds, may he be blessed, spoke them. You also must divide your heart into different chambers and place the words of the school of Shammai and the words of the school of Hillel inside it, the words of those who declare "impure" and those who declare "pure." 34

The beit midrash, where learning grows and multiplies through disagreements, is a place of divine revelation: "One leader gave both." The sparks of divine revelation, each of which can break apart like sparks of fire, representing 
the multitude of opinions, will be revealed in the beit midrash in the form of disagreements. This is similar to the idea, mentioned above, that each individual was made to hear according to his ability and his opinion.

The beit midrash, and the insights into the Torah discovered there, are part of the divine Torah:

\begin{abstract}
Rabbi Berakhiah [said]: Every day God reveals a new legal insight in the celestial beit din. Why? "Just listen to the noise of His rumbling, to the sound (hegeh) that comes out of His mouth" (Job 37:2). There is no "sound" (hegeh) other than the words of Torah, as it is written "Let not this Book of the Teaching cease from your lips, but recite it (vehagita) day and night" (Josh. 1:8). ${ }^{35}$
\end{abstract}

This midrash is more than just a play on the phonetic similarity of the words "hegeh/hagita"; the midrash is saying that the daily legal insights of God in the beit din on high are in fact the insights of the earthly beit midrash where sages study Torah day and night. ${ }^{36}$ This is a reformulation and continuation of the idea, mentioned above, that understands the revelation on Sinai as a beit midrash in which the commandments were heard and interpreted by the listeners.

\title{
The Primordial Beit Midrash: God Turned Two Kidneys into Two Rabbis
}

In several midrashim, the sages went even further. They saw the ongoing Sinaitic revelation as able to rise above and to break free completely from the bounds of space and time until eternity. It was not enough for the sages that they perceived their study as the words of the living God (in the expression of the Babylonian Talmud, tractate Eruvin 13b), all given by the same shepherd. ${ }^{37}$ They reached back to an earlier time, before Sinai, to the Torah-like revelation of God, planted in the inner core of human attention.

Regarding Abraham, Genesis 26:5 says: "Inasmuch as Abraham obeyed Me and kept My charge: My commandments, My laws, and My teachings." The sages interpreted this verse to mean: "Inasmuch as Abraham obeyed Me" Rabbi Aha ... (said): "Abraham even knew the laws of enclosing courtyards." 38 The sages went even further in Bereshit Rabbah 61:

"Happy is the man" (Ps. 1:1) — This is Abraham who did not follow "the counsel of the wicked" ... or take "the path of sinners" ... or join "the 
company of the insolent"... "rather the teaching of the Lord is his delight" ... "and he studies that teaching day and night" (1:1-2). Rabbi Shimon ben Yohai said: "His father did not teach him; he did not have a teacher. How did he learn the Torah? God made his two kidneys like two rabbis and they gushed with wisdom and taught him."39

This midrash makes use of salient imagery, comparing Abraham's kidneys to a beit midrash. They deliberately chose a double, even dialectic, image for the beit midrash, and intentionally used the wording "two kidneys as two rabbis." In the eyes of the sages, the beit midrash, the yeshivah, and divine revelation have existed since the creation of mankind. This is also reflected in the Babylonian Talmud, tractate Yoma 28b:

Rabbi Hama bar Haninah said, "Since the days of our forefathers there has always been a yeshivah. When they were in Egypt they had a yeshivah.... When they were in the desert they had a yeshivah.... Our father Abraham was an elder who studied in the yeshivah.... Our father Isaac was an elder who studied in the yeshivah.... Our father Jacob was an elder who studied in the yeshivah.... Eliezer the servant of Abraham was an elder who studied in the yeshivah, drawing from the well of his master's teachings and giving others to drink. Rav said, "Abraham observed the entire Torah ... even eruvei tavshilin [the laws of preparing food on holidays] as it is said "my Teachings" (Gen. 26:5) — both the Torah and the words of the sages.

Not only the Patriarchs and members of their households studied Torah. ${ }^{40}$ Shem and Eber also had study halls and taught halakhah, as can be seen in Bereshit Rabbah: "'and Jacob was a quiet man, dwelling in tents' (Gen.25:27) — two tents, the beit midrash of Shem and the beit midrash of Eber." ${ }^{41}$ In another midrash, the sages reveal their awareness of the anachronism inherent in their words: "She [Rebekah] went to inquire of the Lord' (Gen. 25:22) -Were there synagogues and study halls in those days? She only went to the beit midrash of Eber! This is to teach us that when one consults an elder, it is as if he approaches the divine presence [shekhinah]." 42 Despite their initial question, the sages held fast to their belief that Rebekah went to the beit midrash of Eber, and thus going to see an elder is comparable to approaching the divine presence. 


\section{"And God Created Man in His Image, in the Image of God He Created Him"}

At this point a serious question arises with regard to the dynamic, innately human capacity to pay attention: Can it be seen as divine revelation? In this context it is worthwhile to review the creation story. When the narrative reaches the creation of man the language becomes lyrical:

And God created man in His image

in the image of God He created him

male and female He created them (Gen. 1:27).

The verse contains three hemistiches, each of which is composed of four units. The verb "to create" followed by a direct object (in Hebrew $b-r-a+e t$ ) appears in each hemistich and the hemistiches are linked: "in his image" - "in the image"; "He created him"- "He created them." I believe that a careful analysis of the verses reveals that the unique quality inherent to man, the "image of God," is the capacity to pay attention. The next verse (28) says:

God blessed them

and God said to them

"Be fertile and increase, fill the earth."

It would appear the narrative is returning to the previous description of the creation of marine life and birds in verse 22 :

God blessed them

saying

"Be fertile and increase, fill the waters in the seas."

However, the contrast between the verses is obvious. The word "saying" in verse 22 (which complements the phrase "God blessed them") uttered on the fifth day, is replaced in verse 28 , in the description of the creation of man, with the word "said" in order to add to it the indirect object "to them," meaning to those listening. This is not the same blessing; man, the image of God, has been endowed with the capacity for conscious attention.

There is an analogy between the words "be fertile and increase" uttered in the context of the creation of man and the statement in the Tosefta mentioned 
above that words of Torah "increase and multiply." In its physical sense, human reproduction increases and multiplies the image of God. From the day that God created man and for eternity, no person has been or will be exactly like another, as the sages said: "The Holy One, blessed be $\mathrm{He}$, cast everyone in the mold of Adam and yet no one is like another." 43 It appears therefore that reproduction is not merely quantitative; each person is a unique innovation. The image of God in each person, his innate divinely revealed capacity to pay conscious attention, is a unique, single spark created only once. This capacity is compelled, and the uniqueness of the capacity of each individual is ten times as compelling. He is not free to desist from his study or his teaching. If he does so, he damages the image of God.

I would now like to expand upon the analogy between reproduction and words of Torah mentioned earlier. Genetics teaches us that each person is imprinted with a specific genetic identity, inherited from his or her parents, and they from their parents, and so forth. Therefore, although each individual is uniquely him or herself, at the same time every person is also a genetic amalgamation of his or her parents. Just as in biology, families and even nations share genetic markers passed down for generations; in the "genetics" of revelation, the divine image is inherited. The unique, dynamic personal attention capacity that is the reflection of the attention capacity of his parents and the icon of the divine image within it, is a unique emanation of the proto-icon of his nation's image. His image of the likeness of God is the glitter of the radiance of the image of the likeness of Adam, the proto-image of mankind. Active attention, discourse, has to bear the conscious, national, multigenerational inheritance as well as the continuous heritage. The deep awareness of "the Lord is One" and "all were given by the one shepherd" obligates discourse and attention flowing in a national genealogical course, in a beit midrash-type existence in which the individual voice is one of the many voices heard in the beit midrash, in an experience in which, on the one hand, there is "everyone," each and every voice, and on the other hand, "all are from the same shepherd" in a chorus of all voices from the beginning to the end of time.

I now return to the meaning of the revelation narratives. These passages lay the foundations for the national consciousness required by the covenant. If one asks how it is possible to behold God, saying "We want to see our King" (as in Exodus), we will answer him that the King is to be seen by hearing his voice (as in Deuteronomy). If one asks how it is possible to hear the voice of the King, saying "We want to hear from the King's mouth," we will answer that the King's voice may be heard by actively listening to the learning process in the 
beit midrash, which bears responsibility for the attention of the divine image. For man was also put on earth for the sake of the awareness of the compulsory national covenant.

Seeking the Torah is seeking God. Adherence to the Torah is adherence to God. As it is said in the Sifrei on Deuteronomy: "'and holding fast to Him' (Deut. 11:22) - How can a person go up to heaven and hold fast to God? He should hold fast to the sages and their students." 44

\section{Endnotes}

1. I will therefore refer only to the classical rabbinic commentators, and only when necessary. I will refer to the work of Arie Tweig, Matan Torah be-Sinai [Lawgiving at Sinai] (Jerusalem: Magnes, 1977), which contains a considerable number of sources.

2. It would appear that this description is based on the image of heaven as the permanent abode of God, found in many other verses including Deut. 26:15; 1 Kings 8:39; Isa. 63:15; and Ps. 2:4, 14:2, 53:3, 76:9, and 123:1. These verses stand in contrast to other biblical verses declaring that God is everywhere (e.g., Ps. 139:8-10); that it is impossible to determine his place (e.g., 1 Kings 8:27); or that his location varies according to the situation (e.g., Gen. $2-3 ; 11: 5)$. Compare Tweig, 47, 100.

3. I will not discuss the relationship between chapter 19 and chapter 24 , which is itself very complicated. There is a break between verses $1-2$, which convey the command to ascend the mountain, and verses 3-8, which describe Moses' arrival (it is not clear from where), the public reading and written recording of the words of God, and the acceptance of the covenant, with accompanying sacrifices. Verses 9-11 ostensibly describe the execution of the order given in verses 1-2, but do not conform to the order in all of its details. Verses 12-18 are rife with problems of continuity-Moses' ascent is related three times (verses 13, 15 , and 18 ), and verse 12 conveys a command that is executed at least three time-as well as other significant problems.

4. Moses ben Nahman (Nachmanides), Perushei ha-Torah le-Rabenu Moshe ben Nahman, ed. Chaim Dov Chavel (Jerusalem: Mosad Harav Kook, 1959), 1:386.

5. These verses are not a direct continuation of what preceding verses and I will not address this issue here. I have discussed these verses and their conceptual position elsewhere: Avraham Shammah, "Va-Yered Ha-Shem al Har Sinai" [The Lord came down upon Mount Sinai], Hag ha-Shavuot (Sidrat Be'er Miriam), ed. Yaakov Medan (Tel Aviv: Miskal, 2012), 126-130. The status of $19 \mathrm{~b}$ is also very unclear. Compare Tweig, 38-40.

6. The tannaim (sages of the Mishnah) noted the discrepancies between the accounts. See Mekhilta de-Rabbi Yishmael, tractate de-ba-hodesh, parashah 4: "The Lord came down upon Mount Sinai' (Exod. 19:20)—On all of the mountain? The Torah teaches: 'On the top of the mountain."

7. For example, Mekhilta de-Rabbi Yishmael, tractate de-ba-hodesh, parashah 2. See the interpretation there. Above, I followed the approach of Rashbam (Rabbi Samuel ben Meir). Compare with the commentary of Abraham Ibn Ezra.

8. See Tweig, 34.

9. No more than "similar" because the idea that the people heard God speak to Moses is not mentioned anywhere else in the Bible. 
10. A detailed discussion of this fragmented type of writing is beyond the scope of this paper. My intention here is only to demonstrate the existence of a central axis of verses in this chapter and identify the verses that are not an integral part of this axis. The conceptual angle of this article is not based on the lack of uniformity or continuity in the biblical text.

11. See Tweig, 14-16 and the literature mentioned there.

12. This verse is also not the continuation of the end of the Decalogue (as Nachmanides pointed out), and this again confirms that the Decalogue is not part of the narrative sequence.

13. "Moses then wrote down all the commands of the Lord.... Then he took the record of the covenant.... I will give you the stone tablets with the teachings and commandments which I have inscribed to instruct them." The exact meaning of the terms mentioned here, as well as their integration in the general system of chapters 19 to 24 , are outside the scope of this article.

14. See Deut. 7:6, 14:2, 26:18, 11:13, 15:5, and 28:1. The complicated position of 3a will not be discussed here. See the commentaries of Ibn Ezra, Rabbi Yosef Bekhor Shor, and Hizkuni and, in contrast, Nachmanides. Compare Tweig, 34-36.

15. A similar point is found in the commentary of Ibn Ezra.

16. Compare Tweig, 38 and 95.

17. The degree of similarity between verses 16-17 and Deut. 5:20-26 will not be discussed here. See Nachmanides on verse 15.

18. Compare Tweig, 53. See also note 16.

19. It seems to me that it is correct to say that all the statements in chapters 19-20 indicating verbal communication between God and man in the core of the revelatory event (not as instructions given in conjunction with the revelation) are not part of the narrative sequence. With regard to verses $3-6$, see above and note 14 ; with regard to verse 9 , see above and note 9; with regard to verse $19 \mathrm{~b}$, see above note 5; with regard to the Decalogue and its introduction, see above and note 11 ; with regard to chapter 20 verses $16-17$, see above and in notes $15-17$.

20. See note 2 .

21. See Tweig, 134.

22. The verses themselves indicate that the people have gathered to hear the Decalogue. A thorough and proper commentary that convincingly demonstrates the integration of the Decalogue itself into Deuteronomy is beyond the scope of this paper. Deuteronomy 4:41-43 suddenly address the allocation of cities of refuge. Verses $44-45$ introduce teaching, decrees, laws, and rules; their meaning is not clear. Verses $46-49$ move on to the conquest of the other side of the Jordan. Deuteronomy 5:1 introduces the proclamation of laws and rules. Verses 2-5 return to the Decalogue on Horeb and are also unclear. Verses 2-3 mention the covenant. Verses $4-5$ refer to the divine speech from the fire and contradict each other: verse 4 says that God spoke "face to face," while verse 5 declares that Moses stood between God and the people. The last word of verse 5 ("saying") leads into the Decalogue but is disconnected from any visible context. This is not the appropriate framework in which to elaborate on these points.

23. The stone tablets mentioned in Exod. 24:12 are devoid of any connection to the Decalogue.

24. Maimonides, Mishneh Torah, Hagigah 3:1-6: "It is a positive commandment to gather all the People of Israel ... and to read to them from the Torah ... that they will hear in reverence, awe and trembling joy as in the day that the Torah was given on Sinai ... and each person will see himself as if he was only now commanded to keep it and has heard it from the mouth of God himself." 
25. See $6: 6-9 ; 11: 18-20$.

26. The concept is not new. The innovation here is its application to the account in Deuteronomy as distinct from the account in Exodus. See Shalom Rosenberg, "'Ha-Hitgalut Ha-Matmedet': Shlosha Kivunim" [The continual revelation: Three approaches], in Hitgalut, Emuna, Tevuna [Revelation, faith, understanding], ed. Moshe Hallamish and Moshe Schwarcz (Ramat Gan: Bar Ilan University, 1976), 131-143.

27. I have distinguished between the visual revelation of Exodus and the verbal revelation of Deuteronomy. To a large extent, these represent different meanings of revelation: the first refers to the revelation of God while the second refers to the revelation of divine attributes. See Rosenberg, “Ha-Hitgalut Ha-Matmedet,” esp. 131.

28. Tractate de-ba-hodesh, parashah 2, 210-211.

29. I noted above the connection of this verse to the account in Deuteronomy.

30. Sifra on Leviticus, ed. E. Finkelstein (New York: JTS, 1983), 9.

31. Compare to parallel texts: Mekhilta de-Rabbi Yishmael, tractate de-ba-hodesh, parashah 4; Mekhilta de-Rabbi Shimon bar Yohai, ed. Jacob Nahum Epstein and Ezra Zion Melamed (Jerusalem: Mekizei Nirdamim, 1956), 144-145. It is interesting that the texts cited above do not mention Nehemiah 9:13, which combines the two accounts: "You came down on Mount Sinai and spoke to them from heaven; You gave them right rules and true teachings, good laws and commandments."

32. Tractate de-ba-hodesh, parashah 9,235

33. Sifre Deuteronomy, piska 313, 355. There is a parallel text in the Mekhilta de-Rabbi Yishmael, tractate de-ba-hodesh, parashah 9, 235: "They heard the commandment 'and interpreted it' . . . they interpreted it."

34. Tosefta, tractate Sotah 7:11-12. See the parallel text in the Babylonian Talmud, tractate Hagigah 3b.

35. Bereshit Rabbah, parashah 64 . See the parallel text in parashah 49.

36. This bold expression is the opposite of the famous saying in the Babylonian Talmud, tractate Bava Metzia 59b: "It is not in the heavens' (Deut. 30:11) —in other words, it is not in heaven but on earth." In contrast, the midrash cited here says that what is seen on earth is really in the heavens. Both are powerful statements, expressing the tension between the word of man and the word of God, and the innovations of the Oral Law that ostensibly do not reflect the Written Torah. This tension is reflected (among other places) in an aggadah in the Babylonian Talmud, tractate Menahot 29b. See also the Jerusalem Talmud, tractate Pe'ah 2:17a and in parallel texts, Megillah 4:74d, Hagigah 1:76d, and other parallels throughout classical rabbinic literature. See Rosenberg, 133.

37. This is similar to the Rava's midrash in the Babylonian Talmud, tractate Avodah Zarah 19a.

38. Bereshit Rabbah, 64 .

39. Ibid., 657.

40. For example, Sarah was "scrupulous about the laws of menstrual purity" (Babylonian Talmud, tractate Bava Metzia 87a, and parallels); Isaac tithed produce (Bereshit Rabbah, parashah 64 and parallels); Jacob observed the entire Torah (Sifrei Deuteronomy, piska 336, 386). See Bereshit Rabbah, parashah 94; parashah 95, and others.

41. Parashah 63. See also parashah 84.

42. Bereshit Rabbah, 63.

43. Babylonian Talmud, tractate Sanhedrin 38a. See also Babylonian Talmud, tractate Berakhot 58a.

44. Piska 49 . 